\title{
ITSによるデータ収集技術を活用した自動車共同利用システムの利用者行動分析* An Analysis on Members' Usage Behavior of Vehicle Sharing System Using Data Derived by ITS Technology ${ }^{*}$
}

\author{
山本俊行 ${ }^{* *}$ - 山本直輝 ${ }^{* * *} \cdot$ 森川高行 ${ }^{* * *} \cdot$ 北村隆一 ${ }^{* * * *}$ \\ By Toshiyuki YAMAMOTO ${ }^{* *}$ Naoteru YAMAMOTO ${ }^{* * *} \cdot$ Takayuki MORIKAWA $^{* * *} \cdot$ Ryuichi KITAMURA ${ }^{* * * *}$
}

\section{1. はじめに}

近年の自動車共同利用プロジェクトでは, システム の効率的な運用を目的としたITS技術の活用が盛んで ある(1), 2). 本研究で対象とする京都パブリックカーシス テム3)でも，インターネットを通じて入会手続きを行 うことで入会手続きに関する人的労力を削减している のを始め, ウェブ上での利用予約システムを用いるこ とにより，オーバーブッキングを防いだり，車両が足 らなくなることを予約システムが管理者に通知するこ とにより，当該デポに事前に車両を回送することも可 能となる. また, 個々の車両にはGPSや通信設備が備 え付けられており, 車両の現在地や充電状態等をセン ターで常に把握することが可能であり，不測の事態に も早急に対応することが可能となる.このように, ITS 技術は共同利用システムの運用効率向上に大きく寄与 するものであるが，それに加えて，システム挙動の詳 細データを自動的かつ継続的に収集し蓄積することが 可能であるという特徵を持つ. 本研究では, このよう に自動的に蓄積されたデータを有効に活用することで, 今後の自動車共同利用システムの運営に資することを 目的とした分析を行う。すなわち，予約システムや車 両管理システムによって収集されたデータを日々のシ ステム運営に用いることをオンライン的活用ととらえ ると, 本研究での分析はオフライン的活用ととらえる ことが出来る.

*キーワーズ : 自動車保有・利用, ITS, 需要分散策

**正員, 博(工), 名古屋大学工学研究科社会基盤工学専攻 (名古屋市千種区不老町, TEL:052-789-4636, E-mail:yamamoto@civil.nagoya-u.ac.jp)

***正員, 修(工)

****正員, Ph.D., 名古屋大学環境学研究科都市環境学専攻 (名古屋市千種区不老町，TEL:052-789-3564, E-mail:morikawa@civil.nagoya-u.ac.jp)

*****正員, Ph.D., 京都大学工学研究科都市社会工学専攻 (京都市左京区吉田本町, TEL: 075-753-5134, E-mail:rkitamura@term.kuciv.kyoto-u.ac.jp)
本稿では, インターネットを通じた予約受付により 収集される予約データと，車両位置把握のために収集 される GPS 車両位置データを用いた分析について報 告する. 予約データの分析では, 需要超過のため予約 拒否された場合の予約変更行動の分析により, 超過需 要の時間分散可能性に関する一般的な知見を得ること を目指す．また，車両位置データの分析では，目的地 と地域属性との関係を分析するとともに, タクシープ ローブカーによる同様のデータと比較分析も行うこと により，新規デポの立地場所に関する知見を得ること を試みる。

再予約行動を含む，より一般的な個人の活動スケジ ューリング行動の観測に関しては, 近年, パソコンを 活用し, 1週間の行動を計画段階から計画変更, 実行段 階まで継続的に調査する試み4), 5), 6)も実施されている. これらの調査では, 被験者が毎晚, 自分の行動予定を パソコンに入力するという非常な負荷が課題となる.

本研究では，全ての行動を対象とするのではなく，共 同利用車両を用いたトリップのみに対象を限定してお り，かつ，パソコン等への入力といった追加的な負荷 をかけることなく，ホテルや列車の予約のように一般 的な生活行動の中でデータが自動的に蓄積されるとい う点に特徴を持っている.

また，車両位置や人の位置の観測に関しては，PHS やGPS等の情報通信技術を活用した調査が試みられて (る7), 8).これらの調查では, 車両や人といった移動体 の時々刻々の位置を把握することによって, 従来の方 法に比べて格段に位置精度の高いデータを得ることに 成功している．ただし，これらの調查を実施するため には, 個々の車両や人に位置計測機器を取り付ける(携 帯させる）ことが必要となり，調查に要する費用が高 額となる場合や，被験者が調查されることを過㮃に意 識して通常とは異なる行動をとる可能性もある. 本研 究では, 共同利用車両の動態管理に用いられているシ 


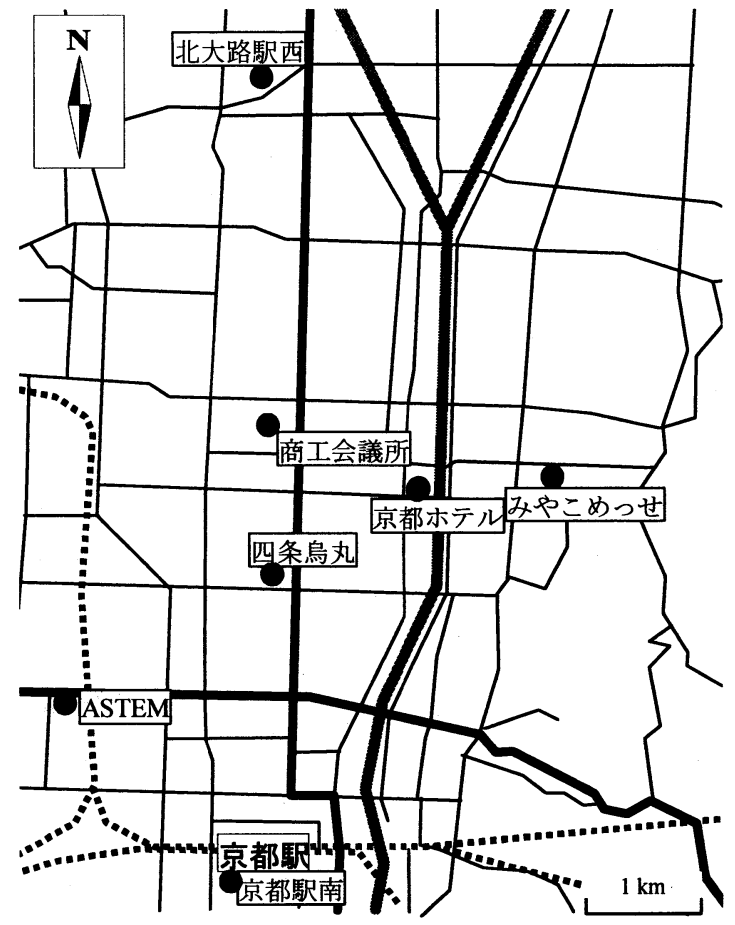

図一1 システム運用地域(山本ら ${ }^{10}$ に加筆修正)

ステムにより得られるデータをそのまま活用すること により, 調查に要する追加的な費用をかけることなく, かつ，被験者が調査されていることを全く気にしない 状態でデータを収集しているという特徴を持つ.

以下,第2章では本研究で対象とする自動車共同利用 システムである, 京都パブリックカーシステムの概要 について説明し,第3章で予約データに基づく分析につ いて報告する．続いて車両位置データを用いた分析を 第4章で報告し, 最後に結論を第5章で述べる.

\section{2. 京都パブリックカーシステムの概要}

京都パブリックカーシステムは，2000～2002年度に 京都市で運用された複数デポ型電気自動車共同利用シ ステムである．2000，2001年度は多くのデポを配した マルチデポ型9)の実験の性格が強く, 2001年度終了時 点での会員数は 470 人となっている.また, 2002年度は, デポを京都駅ととある企業集積地の $2 ヶ$ 所に限定した 運営を行っており，ステーションカー9)的な性格が強 い. 本研究では,より多くのデータが得られている2000 〜2001年度のデータを対象とした分析を行っている.

利用料金は, 当初無料であったが, 2001年9月以降は 20円/分（12月に15円/分に値下げ）に設定されている.
システムの運用地域を図ー1に示す. 2001年度は京都駅 前を含む7カ所 (9月以前は北大路駅西を除く6r所) の デポで運営されており, 営業時間は8:00〜21:00, 1 回 あたりの最大利用可能時間は4時間, 予約開始日は時期 によって変更されているが, 最長時で7日前からであっ た.

車両は 2 人乗り小型電気自動車であるトヨタの e-com と日産のハイパーミニを合計 35 台を用いている. 両車両を単一のシステムで管理しており, 性能もほぼ 同一で, 一回の充電で約 $100 \mathrm{~km}$ 走行することが可能で ある. 充電時間は 2,3 時間程度である.

予約申込は i モードや EZweb 等を含むインターネット， もしくは各駐車場に設置された端末により行う. 予約 申込に際しては, システムの実験的性質のため, 利用 開始・返却の時刻・デポの他に利用目的, 目的施設種 類, 走行予定距離についても申請することとなってい る. また, 貸出・返却時はデポにある端末で各会員が 持つICカードにより手続きを行う．このIC カードは 車両の鍵の代わりでもある.

\section{3. 予約データに基づく分析}

\section{(1) 分析概要}

共同利用システムの事業化を考えた場合，申し込ま れた予約を全て受け付けられれば最も望ましいものの, これまでの実験結果やシミュレーション結果 $\left.{ }^{10)}, 11\right), 12$ ) でも全ての予約を受け付けることは困難である. 一方 で, 車両不足により予約拒否せざるを得ない予約申込 を他の時間や目的地に誘導することが出来ればシステ ム運営の効率性の向上に寄与することになる. ここで は, 京都パブリックカーシステムの運営において予約 拒否が多く発生した2000年度と2001年度の無料時期の 全予約データを用いて, 予約拒否された会員が他の時 間帯や目的地一の再予約を行うか否かに関する分析を 行い, 再予約の発生に寄与する要因, および再予約時 の出発時刻の変更量に影響を及ぼす要因を明らかにす ることを目指す。

本研究では, 予約データを用いて再予約行動を観測 しており，予約が拒否された後の同一会員からの予約 が再予約と見なせるか否かが明示的でない. 本稿では, 予約が拒否された後, 同一会員が同一目的で同一の日 の利用を予約した場合に再予約が行われたものと仮定 
表-1 利用目的別再予約率および再予約時の予約変更内容分布

\begin{tabular}{|c|c|c|c|c|c|c|c|c|c|c|c|}
\hline 選択肢番号 & & 観光 & 業務 & 試乗 & 送迎 & 通院 & 通学 & 通勤 & 買物 & その他 & 合計 \\
\hline & 再予約率 & $46 \%$ & $51 \%$ & $53 \%$ & $49 \%$ & $42 \%$ & $75 \%$ & $36 \%$ & $53 \%$ & $48 \%$ & $49 \%$ \\
\hline 2 & 出 $^{* *}$ & $8 \%$ & $10 \%$ & $9 \%$ & $14 \%$ & $20 \%$ & & $17 \%$ & $10 \%$ & $3 \%$ & $10 \%$ \\
\hline 3 & 終** & $16 \%$ & $23 \%$ & $18 \%$ & $20 \%$ & $60 \%$ & $29 \%$ & $25 \%$ & $28 \%$ & $21 \%$ & $23 \%$ \\
\hline 4 & 目 $^{* *}$ & $8 \%$ & $5 \%$ & $3 \%$ & $20 \%$ & & & $7 \%$ & $7 \%$ & $18 \%$ & $7 \%$ \\
\hline 5 & 出\&終 ${ }^{* *}$ & $33 \%$ & $37 \%$ & $53 \%$ & $20 \%$ & $20 \%$ & $43 \%$ & $26 \%$ & $28 \%$ & $30 \%$ & $33 \%$ \\
\hline 6 & 出\&目 ${ }^{* *}$ & $7 \%$ & $3 \%$ & $9 \%$ & $2 \%$ & & & $1 \%$ & $4 \%$ & & $4 \%$ \\
\hline 7 & 終\&目 ${ }^{* *}$ & $8 \%$ & $4 \%$ & $3 \%$ & $4 \%$ & & & $1 \%$ & $8 \%$ & $9 \%$ & $5 \%$ \\
\hline \multirow[t]{2}{*}{8} & 出\&終\&目 ${ }^{* *}$ & $13 \%$ & $7 \%$ & $6 \%$ & $4 \%$ & & $14 \%$ & $1 \%$ & $8 \%$ & $6 \%$ & $7 \%$ \\
\hline & サンプル数 & 240 & 456 & 64 & 85 & 12 & 16 & 165 & 206 & 62 & 1306 \\
\hline
\end{tabular}

${ }^{*}$ : 選択肢 1 は再予約しない場合

"*: 出は出発時刻, 終は終了時刻, 目は目的地を表す.

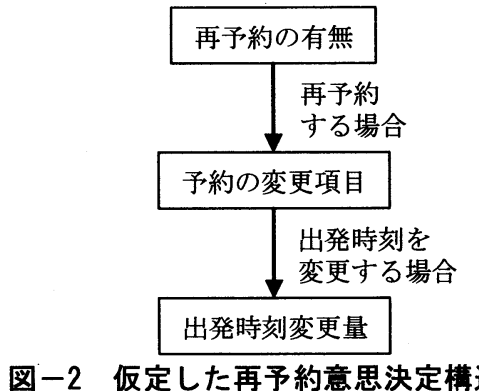

して分析を行っている．別の日にトリップを変更する といった再予約行動も含めて分析するには, アンケー 卜調査等の実施が必要であると考えられる.

再予約行動のモデル化にあたっては, 図ー2に示す意 思決定構造を仮定した，すなわち，はじめに再予約を 行うか否かを決定し, 続いて, 再予約する場合の予約 変更項目を決定する. 最後に, 出発時刻を変更する場 合の変更量を決定するという構造である。このうち， 再予約の有無と予約の変更項目については相互作用を 考慮した分析を行う, また, 出発時刻変更量に関して は，以下に示寸需要分散効果の観点から，特に取り上 げて分析を行う。

共同利用システムの再予約行動は, より一般的なス ケジューリング変更行動の一種と考えられる.よって, 本分析で得られる結果は, より一般的な超過需要の時 間的分散方策に関する基礎的な知見をも提供すること が期待される.

\section{（2）再予約行動の分析結果}

はじめに，利用目的別の再予約率および再予約時の 予約変更内容の分布を表-1 に示す．表より，通勤では 再予約率が低いことが分かる。これは，通勤の自由度 が低いことが原因と考えられ，通勤利用をシステムに
取り込むためには, 2000 年度の実験で実施したように, 毎日の利用をあらかじめ予約しておくといった方法が 不可欠であることを示している，一方で，再予約時の 予約変更内容の分布を見ると, 出発時刻と終了時刻を 同時に変更している割合は試乗, 通学, 業務の順で多 く, これらの活動の時間拘束性が低いことが分かる. ただし, 通学はサンプル数が少ないことに注意が必要 である。これより, 業務は, 需要の時間的分散の観点 からも共同利用システムに適した利用目的であること が分かる.

次に, 再予約選択行動に影響を及ぼす要因を探るた め, 出発時刻の変更, 終了時刻の変更, 目的地の変更, そしてそれらの組み合わせ, それに加えて再予約をし ないという選択肢を加え, 合計 8 つの選択肢集合を設 定し, 再予約行動を離散選択行動と捉えたモデル分析 を行った. 離散選択行動のモデルにはロジットモデル の枠組みを適用し, 再予約の有無と予約の変更項目の 選択の相互作用を考慮した．すなわち，再予約の有無 を上位レベル，予約の変更項目の選択を下位レベルと したネスティッド・ロジットモデルを構築した。しか しながら, 推定作業の結果, 再予約を行う場合の 7 選 択肢間の相関を表すログサム変数值が 1 から有意に離 れておらず，再予約の有無と予約の変更項目の選択は 同時選択であることが確認された.

次に，予約の変更項目の選択においては，出発時刻 や終了時刻，目的地のそれぞれの変更の組み合わせが 選択肢となっているため，選択肢間に相関を持つ可能 性が考えられる. 本研究では, 上記の 3 つの変更項目 のそれぞれについて共通の誤差項の存在を仮定した mixed logit model ${ }^{13)}$ を適用した。すなわち，表-1の選択 肢 $(2,5,6,8),(3,5,7,8) ，(4,6,7,8)$ の誤差項間にそれぞ 
表-2 再予約選択行動モデル

\begin{tabular}{|c|c|c|c|c|c|}
\hline 説明変数 ${ }^{*}$ & 推定値 & $\mathrm{t}$ 值 & 説明変数 & 推定值 & $\mathrm{t}$ 值 \\
\hline 定数項(出) & -1.843 & -11.19 & 買物(終\&目) & 0.857 & 1.98 \\
\hline 定数項(終) & -1.736 & -9.71 & 年齢(目) & -0.047 & -2.63 \\
\hline 定数項(目) & -0.808 & -1.29 & 女性(出＆終) & 0.830 & 1.99 \\
\hline 定数項(出\&終) & -1.059 & -6.55 & 利用時間(終) & 0.0027 & 3.29 \\
\hline 定数項(出\&目) & -8.886 & -6.06 & 利用時間(出\&終) & 0.0023 & 3.03 \\
\hline 定数項(終\&目) & -3.222 & -7.64 & 利用時間(終\&目) & -0.0046 & -2.13 \\
\hline 定数項(出＆終＆目) & -2.173 & -14.25 & 前日予約(出) & -1.189 & -2.42 \\
\hline 業務(出＆終) & 0.326 & 2.06 & 前日予約(出＆終) & -1.416 & -5.97 \\
\hline 送迎(出) & 0.905 & 2.04 & 前日予約(終\&目) & 0.887 & 1.91 \\
\hline 送迎(目) & 1.147 & 2.54 & 前日予約(出\&終\&目) & -1.175 & -2.46 \\
\hline 通勤(否) & 1.956 & 3.25 & 当日事前予約(終) & 0.080 & 2.31 \\
\hline 通勤(出) & 1.864 & 2.42 & 当日事前予約(出＆終) & -0.148 & -3.14 \\
\hline 通勤(終) & 1.696 & 2.61 & 当日事前予約(終\&目) & 0.235 & 4.59 \\
\hline 通勤(目) & 1.761 & 2.29 & 出発時刻(出＆目) & 0.388 & 4.41 \\
\hline 通勤(出＆終) & 1.504 & 2.34 & & & \\
\hline サンプル数 & & & & & 1264 \\
\hline 初期尤度 & & & & & -2628 \\
\hline 最終尤度 & & & & & -1659 \\
\hline
\end{tabular}

れ相関があるものと仮定したモデルの推定を行った. その結果, 目的地を変更する選択肢 $(4,6,7,8)$ 間のみ に相関が存在することが統計的に確認された.ただし， 尤度比検定の結果, 多項ロジットモデルと有意な差は 見られなかった。

最後に，目的地を変更する選択肢間に相関があるも のと仮定したネスティッド・ロジットモデルを構築し たところ, mixed logit model の結果と同様に誤差項間 の相関の存在が統計的に確認された. しかしながら， 尤度比検定の結果, やはり多項ロジットモデルと有意 な差は確認されなかった。 以下では, 多項ロジットモ デルの推定結果について考察を行う.

多項ロジットモデルの推定結果を表-2 に示す. 表よ り，利用目的によって再予約行動が大きく異なること が確認された. 特に, 業務目的の場合, 出発時刻と終 了時刻を同時に変更する形で再予約する確率が高くな っており, 業務目的トリップの自由度の高さが確認さ れた。一方で, 通勤目的トリップは再予約しない確率 が最も高い結果となり, 通勤トリップの時間選択自由 度のなさが確認された. その他, 個人属性としては, 女性の方が出発時刻と終了時刻を同時に変更する確率 が高く，時間的自由度が高いことが示された。

利用時間に関しては, 予約して利用を予定していた 時間が長いほど終了時刻を変更したり, 終了時刻とそ の他の変更を組み合わせたりする確率が高くなってお
表-3 出発時刻変更時の変更後出発時刻

\begin{tabular}{lrr} 
& \multicolumn{2}{c}{ 割合 サンプル数 } \\
\hline 1 時間以上前 & $4.2 \%$ & 16 \\
30 分以上前 & $3.1 \%$ & 12 \\
前後 30 分以内 & $74.5 \%$ & 287 \\
30 分以上後 & $6.8 \%$ & 26 \\
1 時間以上後 & $11.4 \%$ & 44 \\
合計 & $100.0 \%$ & 385 \\
\hline
\end{tabular}

り，利用時間の短縮によって予約拒否に対応しょうと する傾向が伺える. 最後に, 予約を申し込む時点から 実際の利用までの時間では, 前日以前に予約拒否され た場合の方が当日に予約拒否されるより出発時刻を変 更する確率は低いことが示された. 当日でも, より事 前に予約拒否された場合は終了時刻を変更する確率が 高く, 出発までの時間が迫っていないほど出発時刻を 変更しないという結果となった. 反対に. 出発間際に 予約が拒否されると出発時刻を後ろにずらさざるを得 ないということを反映しているものと考えられる.

\section{（3）出発時刻の変更量の分析結果}

ここでは, 予約変更時に出発時刻を変更する場合, その変更時間はどの程度か, そして変更時間はどのよ うな要因によって影響を受けるかを分析することで, 需要の時間的分散のためにどのようなトリップを変更 させることが可能かに関する知見を得ることを目指す. 
表-4 出発時刻変更量モデル

全体遅らせる場合早める場合

\begin{tabular}{lrrrrrr} 
説明変数 & 推定値 & \multicolumn{1}{c}{$\mathrm{t}$ 値 } & 推定値 & \multicolumn{1}{c}{$\mathrm{t}$ 值 } & 推定値 & \multicolumn{1}{c}{ 値 } \\
\hline 定数項 & 5.70 & 56.26 & 5.65 & 47.53 & 6.43 & 38.02 \\
事前予約 & 0.50 & 11.58 & 2.67 & 7.95 & 0.23 & 4.56 \\
前日予約 & 2.39 & 9.12 & 0.52 & 8.26 & 0.95 & 2.85 \\
目的地駐車場満車 & -0.96 & -5.07 & -0.99 & -4.49 & & \\
終了時刻が遅すぎる & -0.91 & -3.87 & -1.14 & -3.72 & & \\
開始時刻が早すぎる & 1.63 & 3.10 & 1.55 & 2.78 & & \\
利用時間超過 & -1.07 & -3.09 & -1.02 & -2.76 & & \\
観光 & -0.48 & -2.65 & -0.56 & -2.75 & & \\
通学 & & & & & -1.80 & -2.49 \\
買物 & & & -0.58 & -2.02 & & \\
\hline サンプル数 & & 385 & & 308 & & 77 \\
$R^{2}$ & & 0.42 & & 0.43 & & 0.30 \\
$\bar{R}^{2}$ & & 0.41 & & 0.42 & & 0.27 \\
\hline
\end{tabular}

表-3 に出発時刻変更時の変更後出発時刻分布を示す. 表より,ほとんどの変更が初期の予定の前後 30 分以内 に固まっており，全体としては大きな時間的分散効果 は期待できないことが示された．ただし，1 時間以上 も予定を遅らせているトリップも $10 \%$ 以上存在してお り, このような需要の分散によって, 一定程度の需要 の分散は可能であることも明らかとなった。

次に, 出発時刻の変更量を被説明変数として重回帰 モデルを構筑した結果を表-4に示す．ただし，モデル は全ての変更ケースを用いたもの, 出発時刻を遅らせ たもの, 出発時刻を早めたもの, の 3 通りについて推 定を行っている. また, 出発時刻の変更量は対数をと ったものを被説明変数に用いた．表より，いずれのモ デルでも事前予約および前日予約の推定值が有意に正 の値をとっており，予約から出発予定時刻までに時間 や日数があるほど変更量が大きいことが示された．再 予約選択行動モデルの結果と合わせると，予約から出 発時刻までに時間や日数があるほど出発時刻の変更の 確率は低いが，一旦出発時刻を変更することを決定し た場合には，出発時刻を大幅に変更する確率が高いこ とが分かる．需要の時間的分散を図るには，大幅に出 発時刻を変更させることが必要であり，早期の予約受 付の効果が高いことを示寸ものであると考えられる. ただし，再予約選択行動モデルでは，業務トリップが 自由度が高く, 需要の分散に適しているとの結果が得 られたが，業務トリップが早期に予約可能か否かは不
明である．業務トリップには，時間に指定のない配達 のようなトリップから，取引先の都合に合わせた急な 商談まで様々な業務が含まれているため，早期に予約 可能で, かつ, 出発時刻に自由度の高い業務トリップ の把握が必要である．詳細な分析にはアンケート調査 等が必要であり, 今後の課題としたい.

\section{4. 車両位置データを用いた新規デポ候補地の検討}

\section{(1) 分析目的}

自動車共同利用システムの効率化に重要な要因とし て，どこにデポを立地するかという問題がある．会員 に対するアンケート調查でも，利用し易い場所にデポ を希望する，すなわち，現状のデポ位置に不満のある 層は利用頻度が低いという結果が得られている.デポ の立地は周辺会員の利用頻度を規定するのみならず， 他のデポからの片道トリップの目的地として利用され るという側面もあるため，周辺土地利用が潜在的な優 良会員を含むかどうかに加えて，デポ周辺にトリップ 目的地となる施設が存在するかという要素も考慮する 必要がある.ここでは, 2000 年度, 2001 年度の実験で 車両管理のために GPS により時々刻々と把握してい た車両位置データを用いて, トリップ目的地がどのよ うな土地利用属性を持つ地域であるかに関する分析を 行う.GPSによって車両管理を行っていたのは共同利 用車のうち e-com の 20 台であり，本稿では 20 台の車 


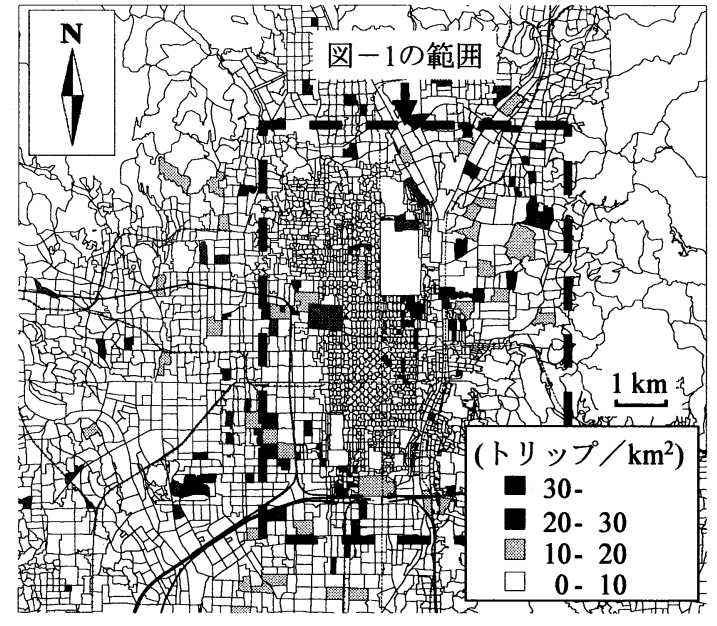

図-3 共同利用車両のトリップ目的地分布

両の 2000 年度と 2001 年度の全トリップの位置データ を用いた分析を行う．さらに，事業化時に共同利用へ 転換することが期待されるタクシートリップのトリッ プ目的地についても, 名古屋で実施中のプロジェクト で得られたデータに基づいて同様の分析を行い，本実 験データとの比較を行う。

\section{（2）共同利用車両位置データの分析結果}

本実験で収集された車両位置データは, 共同利用車 両のうち 20 台に搭載されていた携帯電話端末の位置 情報通信機能によってセンターに収集されたものであ り, 車両位置が約 5 分間隔で記録されている.ただし, 本実験では，片道利用トリップ等で目的デポに車両を 返却してから本来の目的地に赴くケースがあるが，そ のような場合には車両位置から目的地を特定すること は不可能である. 本分析では, 5 分毎の車両位置デー タを GIS 上にプロットし, 各車両の軌跡を線でつなぎ, 線でつないだ位置データの前後の 2 点かそれ以上の連 続した点で, 前の点の座標と次の点の座標位置が同じ である場合に,その座標位置を目的地とした.

共同利用車両トリップの目的地分布図より, 京都駅 付近や ASTEM など, デポが目的地として多く示され たが，上述のようにこれらは真の目的地とは言えない ので注意が必要である.デポのある町丁目を取り除い たトリップ目的地分布図を図ー3に示す. デポ以外の 目的地では, 京都府庁や市役所などの政府機関や西京 極付近, 二条城, 京都御所などの観光地に集中してい る様子が伺える.このような地域は目的地としてのデ

\begin{tabular}{lrr} 
表 -5 & \multicolumn{3}{l}{ 共同利用車集中トリップ数モデル } \\
\hline 説明変数 & 推定値 & $\mathrm{t}$ 值 \\
\hline 定数項 & 0.128 & 0.21 \\
人口 $\left(/ \mathrm{km}^{2}\right)$ & 0.002 & 2.35 \\
全産業事業所数 $\left(/ \mathrm{km}^{2}\right)$ & 0.003 & 2.17 \\
\hline サンプル数 & 500 \\
$R^{2}$ & 0.237 \\
\hline
\end{tabular}

ポの利用が見込まれるため，新規デポの立地候補とし て検討の余地があると考えられる。

次に, 各町丁目への単位面積 $\left(1 \mathrm{~km}^{2}\right)$ あたりの集中 トリップ数を被説明変数として, 地域の人口や世帯数, 商業統計，事業所統計との関連を分析するために重回 帰モデルを構築した。推定に際しては，町丁目は非常 に多いためサンプル数が膨大になり推定の計算負荷が 大きいため, 乱数により 500 の町丁目を抽出し, 抽出 された町丁目を対象としてモデルの推定を行った。集 中トリップ数に影響を及ぼす地域属性については, 町 丁目毎の集計値を用い単位面積あたりの值を算出して 説明変数に用いた. 通常の目的地選択モデル等では, 隣接ゾーンの影響を考慮するためより大きなゾーンの 平均值を用いる場合が多いが，本研究のように自動車 による目的地での駐車を考えた場合，目的地と同町丁 目に駐車する可能性が高いと考えられるため，本稿で は隣接ゾーンの影響は考虑しない。

推定結果を表-5に示す. 観測されたトリップ目的地 数が少なかったためか，ほとんど有意な変数が得られ なかったものの, 人口総数と全産業事業所数が正に有 意な值となっており，それらが共同車両のトリップの 目的地となることが確認された. より詳細な分析を行 うためには，個々のトリップを用いた非集計離散選択 モデルを適用した目的地選択モデルの構築等が考えら れる。

\section{（3）タクシープローブデータの分析}

上記の分析では，観測されたトリップ目的地数が少 なかったためか，集中トリップ数に影響を及ぼす要因 の特定が十分に行えなかった。そこで，事業化時に共 同利用一転換することが期待されるタクシートリップ を対象として，同様にトリップ目的地の分析を行うこ とによって，新規デポの立地場所に関する知見を補足 することを試みる.

タクシートリップは共同利用システムと同様に, 利 用毎に費用を負担する点に共通点があるものの，利用 


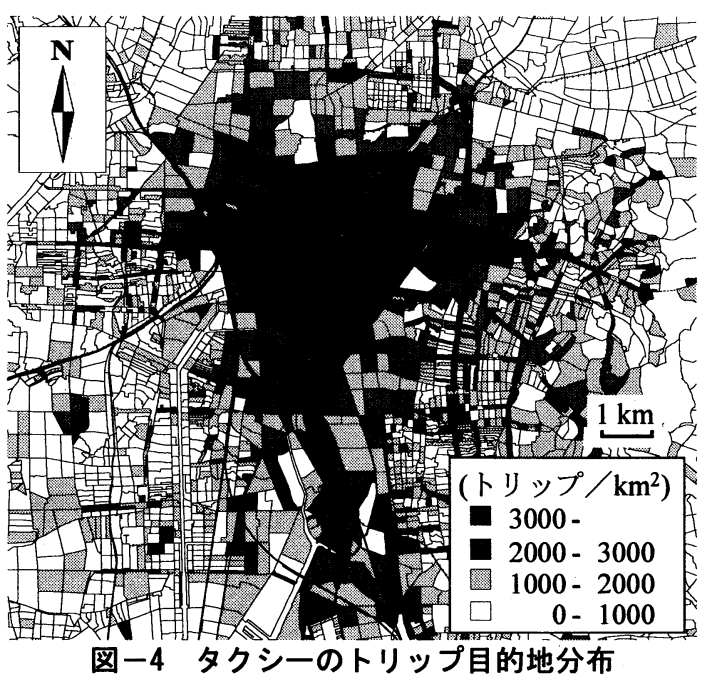

距離帯や料金設定，共同利用システムには利用時間に 制限がある等，両者の相違も大きい，ここでは，(2) の分析手法の妥当性の確認, および, タクシートリッ プから共同利用システムへの転換可能性という点に着 目して分析を行う。

本分析で用いるタクシーの位置データは，2001年度 に名古屋において実施されたInternetITSプロジェクト で収集されたデータである．プロジェクトでは，約 1,500台のタクシーにGPS車載機を取り付けており，デ 一夕項目には, 日時 - 速度 - 進行方向 ・加速度 · SS, STフラグ・実車, 空車フラグなど様々なものがある. データの送信は主に発進・停止時, 直前のデータ送信 から $300 \mathrm{~m}$ 走行時, または550秒経過後などに行われる. このような車両位置データのことをプローブデータと 呼ぶ. 本プロジェクトの詳細については三輪ら ${ }^{14) を}$ 照されたい。

共同車両トリップデータと同様に，タクシートリッ プの目的地を集計した分布図を図ー4に示す. 図より, 共同利用車両トリップデータと異なり, タクシートリ ップデータの場合には，全ての目的地が観測されてお り，また，車両台数も格段に多いため，分布図に示さ れている目的地数も格段に多くなった．また，名古屋 駅, 栄地区といった名古屋市の中心的位置で到着数が 多く，郊外ほど少なくなっていることが分かった。さ らに, 幹線道路沿いでトリップ目的地数の多い町丁目 も見受けられた。

次に, 共同利用車両集中トリップ数モデルと同様に, 乱数により抽出した町丁目を対象として単位面積
表-6 タクシ一集中トリップ数モデル

\begin{tabular}{lrr}
\hline 説明変数 & 推定値 & \multicolumn{1}{c}{$\mathrm{t}$ 值 } \\
\hline 定数項 & -172.4 & -15.55 \\
人口 $\left(/ 1 \mathrm{~km}^{2}\right)$ & 0.06 & 9.82 \\
全産業事業所数 $\left(/ \mathrm{km}^{2}\right)$ & 1.102 & 17.54 \\
買回り品業種売場面積 $\left(/ 1 \mathrm{~km}^{2}\right)$ & 0.083 & 20.90 \\
駅から $500 \mathrm{~m}$ 以上ダミー & -48.8 & -3.28 \\
第2 次産業男性従業者数 $\left(/ 1 \mathrm{~km}^{2}\right)$ & 0.122 & 4.85 \\
\hline サンプル数 & & 1000 \\
決定係数 & & 0.239 \\
\hline
\end{tabular}

$\left(1 \mathrm{~km}^{2}\right)$ あたりのタクシー集中トリップ数を被説明変 数とした重回帰モデルを構筑した. 推定結果を表-6に 示す. 表より, 共同利用車両集中トリップ数モデルと 同様に，人口総数，および全産業事業所数が正の值を とっており，タクシートリップにおいてもそれらが目 的地となることを示している. さらに，買回り品業種 売場面積も有意に正の值をとっており，これらの施設 もトリップ目的地となることを示している. 反対に, 駅から $500 \mathrm{~m}$ 以上の地域では, 集中トリップが少なく, 駅から鉄道に乗るためにタクシーが利用されているこ とが分かる. 最後に, 第 2 次産業男性従業員数がタク シー集中トリップ数に正の影響を与えていることが示 されているが，第 2 次産業では第 3 次産業に比べて女 性の進出が遅れており，どちらかというと男性が外部 との打ち合わせに出席することが多いことがこのよう な結果をもたらしているのではないかと推測される.

以上の結果はタクシートリップを対象としたもので あり共同利用システムのデポ立地検討に直接適用でき るものではない。しかしながら，タクシートリップに おいて駅周辺が顕著な目的地となっていることは，今 後の共同利用のデポ立地を考える上で, 鉄道駅へのデ ポ立地による鉄道との連携を重視することが重要であ ることを示唆するものである．ステーションカー型の 共同利用システムでは鉄道駅との連携に特化した共同 利用の形態であるが，それ以外の共同利用システムに おいても，鉄道駅との何らかの連携を検討すべきであ ると考えられる.

\section{5. おわりに}

本稿では, 車両共同利用システムの効率化を念頭に, インターネットを通じた予約受付により収集される予 約データと, 車両位置把握のために収集される GPS 車 
両位置データを用いた分析を行った。

予約変更行動に関する分析結果より, 業務目的トリ ップや女性会員は出発時刻を変更する確率が高く，共 同利用システムの会員に適した特性を持っていること が示された. また, 通勤トリップは出発時刻を変更す る可能性が低いことが確認された．通勤トリップに対 しては，1 ケ月間まとめての予約等が必要であること が確認された.この知見は既に 2002 年度の京都パブリ ックカーシステムの実際の運営に反映されている.さ らに，出発時刻を 1 時間以上も変更するケースも $10 \%$ 以上存在し, 早期の予約受付が需要の分散に効果が高 いことも確認された.

本共同利用システムでは，実験的性質のため，利用 予約時に利用目的を質問しており上記の分析が可能で あったが，通常は利用目的まで収集されたデータは少 ない. 今後の共同利用システムの運営効率化のために も, 利用者の負担が増えない程度に利用目的を質問し， 分析に活かす事は有効であると考えられる.

車両位置データを用いた分析では，共同利用車の目 的地データからは，特に有益な知見を導き出すことは 出来なかったものの, 同様の手法をタクシートリップ のデータに適用することによって, デポ立地に関して 駅や商業施設との連携の重要性を示唆された. 車両位 置データには, 地理情報に加えて詳細な利用時刻情報 も得られており, これを加味した分析は今後の課題で ある。

以上のように, ITS 技術によって収集されたデータ を用いることで, 従来では観測することが困難であつ た, 行動のスケジュール過程に関する分析や地理平面 上の詳細な位置データを用いた分析が可能になったが， 再予約データには，共同利用システムを利用しない形 でスケジュールを変更した場合にどのような変更を行 ったかが含まれていない. また, 車両位置データには, 片道利用でデポに車両を返却した後で本来の目的地に 赴く場合の本来の目的地が含まれていない。このよう に，ITS 技術によってデータの詳細度やデータ量は格 段に増えたものの, データの不完全性という問題が浮 き彫りになった，今後は，SP/RP モデルのように，複 数ソースからのデータを統合した分析の必要性が高ま ることが予想される.

\section{謝辞}

本研究は, 文部科学省科学研究補助金（若手研究） を得て実施された研究成果の一部である. また，原稿 の執筆に当たり，3 名の査読者に有益なコメントを得 た.ここに記して感謝の意を表します.

\section{参考文献}

1) Barth, M., Todd, M. and Murakami, H.: Intelligent transportation system technology in a shared electric vehicle program, Transportation Research Record, No. 1731, pp. 88-95, 2000.

2) Barth, M., Todd, M. and Shaheen, S.: Examining intelligent transportation technology elements and operational methodologies for shared-use vehicle systems, Preprint CD-ROM of the 79th Annual Meeting of Transportation Research Board, Washington D.C., 2003.

3) 京都パブリックカーシステムホームページ : http://www.ev-kyoto.com/

4) Doherty, S.T. and Miller, E.J.: A computerized household activity scheduling survey, Transportation, Vol. 27, No. 1, pp. 75-97, 2000.

5) Lee, M. and McNally, M.G. Experiments with a computerized self-administrative activity survey, Transportation Research Record, No. 1748, pp. 125-131, 2001.

6) Lee, M. and McNally, M.G.: On the structure of weekly activity/travel patterns, Transportation Research Part A, Vol. 37, pp. 823-839, 2003.

7) 朝倉康夫・羽藤英二・大藤武彦・田名部淳 : PHS による 位置情報を用いた交通行動調查手法, 土木学会論文集, No. 653/IV-48, pp. 95-104, 2000.

8) 上杉友一・井料隆雅・小根山裕之・堀口良太・桑原雅夫 : 断片的なプローブ軌跡の接合による区間旅行時間の期 待値と分散の推定, 土木計画学研究・論文集, Vol. 20, pp. 923-929, 2003

9) Barth, M. and Shaheen, S.A.: Shared-use vehicle systems: framework for classifying carsharing, station cars, and combined approaches, Transportation Research Record, No. 1791, pp. 105-112, 2002.

10) 山本俊行・中山晶一朗・北村隆一 : 再配車を用いない複 数ステーション型自動車共同利用システムの挙動に関 するシミュレーション分析, 土木学会論文集，(投稿中).

11) 中山晶一朗, 山本俊行, 北村隆一: 再配車によらない電 気自動車の共同利用システムの効率化に関する研究, 土 木計画学研究・論文集, Vol. 19, pp. 481-487, 2002.

12) Nakayama, S., Yamamoto, T. and Kitamura, R.: Simulation analysis for the management of an electric vehicle-sharing system: case of the Kyoto Public Car System, Transportation Research Record, No. 1791, pp. 99-104, 2002.

13) McFadden, D. and Train, K.: Mixed MNL models of discrete response, Journal of Applied Econometrics, Vol. 15, pp. 447-470, 2000.

14）三輪富生・森川高行・岡田良之 : プローブデータによる OD 表の作成と経路選択行動の分析, 第 1 回 ITS シンポ ジウム, pp.591-596, 2002. 


\section{ITSによるデータ収集技術を活用した自動車共同利用システムの利用者行動分析*}

$$
\text { 山本俊行 }{ }^{* *} \cdot \text { 山本直輝 }{ }^{* * *} \cdot \text { 森川高行 }{ }^{* * *} \cdot \text { 北村隆一 }^{* * * *}
$$

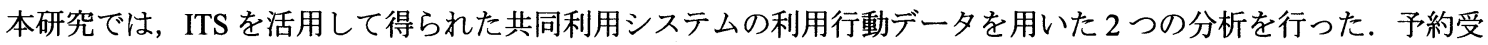
付システムに記録された予約行動データを用いた再予約行動の分析では，業務トリップや女性会員が時間変更を行 う確率が高いことが示された．これらの結果は，会員募集の際の有望な対象を示すだけでなく，より一般的に，需 要超過時の需要分散策の対象としても有望であると考えられる.また，車両の動態管理に用いられている車両の位 置データを用いたトリップ目的地の分析を行った．従来のアンケート調査に比べて詳細な位置データに基づき，共 同利用システムのデポ立地に関して駅や商業施設との連携の重要性を確認した.

\section{An Analysis on Members' Usage Behavior of Vehicle Sharing System Using Data Derived by ITS Technology ${ }^{*}$ \\ By Toshiyuki YAMAMOTO** ${ }^{* *}$ Naoteru YAMAMOTO ${ }^{* * *}$ - Takayuki MORIKAWA ${ }^{* * * *} \cdot$ Ryuichi KITAMURA $^{* * * *}$} Two analyses were carried out with the data sets on user behavior of a vehicle sharing system, which were efficiently obtained by the ITS technology. The analysis on the rescheduling behavior through an web-based reservation system revealed that business trips and female members have a higher probability of changing trip timing than other trip purposes or male member. The results suggest the target segments for general demand dispersions as well as the membership recruiting of the sharing system. The analysis on the trip destination was also carried out with the data set obtained from the GPS-based vehicle location identification system. The results confirm that the parking spaces of the sharing system should be located close to railway stations or shopping destinations. 